Proceedings of the 1st international conference Economic and Business Trends Shaping the Future | 2020

\title{
THE COST OF NEGATIVE INCOME TAX AS A FISCAL MEASURE TO TACKLE POVERTY IN NORTH MACEDONIA
}

\author{
Ivana Velkovska \\ Faculty of Economics - Skopje, Ss. Cyril and Methodius University \\ ivana89velkovska@gmail.com
}

\begin{abstract}
:
This paper makes an effort to evaluate the cost of negative income tax as a fiscal measure aiming to tackle the persistent high poverty rate in Macedonia. Poverty, income inequality and unemployment are expected to rise all around the world due to the pandemic corona virus outbreak and the subsequent economic crisis. Governments around the world have already implemented measures similar to universal basic income with the purpose of increasing household consumption and stimulating aggregate demand but also to mitigate the devastating effects that the recent unfavorable economic developments have on the citizens living in poverty or are at the risk of poverty. However, shrinking fiscal spaces of small economies could be an obstacle to implement such policies. Compared to universal basic income, negative income tax is a less costly policy option that targets the population living in poverty instead of providing payments to everyone regardless of their income. The analysis based on the available data is indicating that implementing such policy would cost as much as 9.7 billion MKD per year, which is $4 \%$ of the planned state budget revenues for Y2020, 8\% of the planned social transfers for Y2020 and 29\% of the funds that the state has made available for tackling the COVID 19 crisis so far. In addition, the negative income tax could trigger various positive effects on the economy. Since poor people spend almost all of their income, it could be expected that implementing negative income tax would rise household consumption. According to the empirical analysis in this paper, household consumption is in highest correlation to GDP growth in Macedonia compared to the other explanatory variables (government consumption, investments, import and export).
\end{abstract}

Keywords: negative income tax, welfare, government expenditures, household consumption

JEL classification: H230, I3, H75, H31

\section{INTRODUCTION}

The already high number of people living in poverty in Macedonia is expected get even higher with the ongoing corona virus pandemic outbreak. This number could increase as a result of rising unemployment but also due to the rise in the income inequality and the number of the "working-poor" because those who remain in employment could receive lower wages caused by the significant economic contraction. This paper will make an effort to estimate the cost of the negative income tax policy as a potential government measure to tackle the persistent poverty, unemployment and income inequality in the country which is expected to be exacerbated by the pandemic and subsequent economic crisis.

http://doi.org/10.47063/EBTSF.2020.0002

http://hdl.handle.net/20.500.12188/9708 
Measures similar to the idea of universal basic income have already been implemented by several countries as a respond to the pandemic and economic crisis, but these policies are not always suitable for small economies with limited fiscal space because they tend to cost a significant amount of budget resources. A less costly solution that could potentially tackle the same problem of elevated poverty is the implementation of a negative income tax as a policy that is more targeted than universal basic income which provides everyone with the same amount of cash payments regardless whether they are rich or poor. The central idea of the negative income tax policy is to provide the poor with the amount they are missing in order to help them reach the poverty threshold level of income that is crucial for living a dignified life, improve standards of living, escape the traps of poverty and contribute to increasing the overall household consumption. Accordingly, this amount would be equal to the difference between the amount of "poverty threshold income" and the income the poor already earn or receive through social transfers or pensions.

Since negative income tax has never been implemented in any country and has been out of policy debates for a long time, it represents an unconventional and to many an unfamiliar policy option. In addition, speculations about the costs of such measure could easily and prematurely label it as expensive and financially unfeasible. However, policymakers should not forget about the costs of poverty, unemployment and income inequality as well. These costs are arising from to the negative effects that they have on the economy and these challenging times call for innovative and brave solutions. It should be taken into consideration that the true cost of the negative income tax would be the net difference between the positive benefits such measure could have on the overall economy through stimulating household consumption and the financial state budget burden the measure would trigger.

This analysis will make an effort to provide an estimation of the costs of this potential fiscal measure based on the available data. It will also try to measure the potential beneficial effects it could have on the economy by measuring how stimulating household consumption could impact the economic output in Macedonia using time series analysis. The second section of the analysis will provide a theoretical background of the negative income tax policy and enclose some relevant data leading us to the third section where the initial calculations of the costs of the negative income tax policy are presented. The fourth section of this paper presents the results of the empirical analysis on the relationship between the economic growth and the household consumption that is expected to increase in case a measure such as the negative income tax is implemented. The last fifth section is presenting the concluding remarks of this analysis.

\section{THEORETICAL BACKGROUNG AND SOME STYLIZED DATA}

The concept of negative income tax is rarely discussed in both academic circles and policy debates thus remaining relatively unfamiliar to many. However, it is a rather simple concept and an opposite one to the concept of positive income tax when citizens pay taxes to government. Accordingly, the policy of the negative income tax would mean that citizens receive income from the government in a way that is similar to social transfers.

Practically, implementing a negative income tax would mean that those citizens who earn or receive (through social transfers or pensions) an income that is lower than the poverty threshold income (usually defined as $60 \%$ of the median equalized income) are going to receive the missing amount to reach the poverty threshold, thus becoming citizens who are able to have an adequate standard of living (which is a basic human right) that is high enough to provide for a dignified life and are able to contribute to the economy through increasing household 
consumption and hopefully escape the traps of poverty by using this income to live healthy, to stay in education and out of the gray economy.

High income inequality, poverty and increasing unemployment risks due to the fourth industrial revolution, make the existing social protection systems obsolete and ineffective. Nowadays the countries are facing yet another challenge - the economic crisis caused by the coronavirus pandemic outbreak. The latest global estimates by the ILO, indicate that 'more than four out of five people -81 percent of the global workforce of 3.3 billion - are currently affected by full or partial workplace closures' (ILO, 2020). These changes in the labour market are expected to rise the levels of income inequality, poverty and unemployment even further and make these issues even more relevant today than they were before. In addition, the decline in aggregate demand is making the importance of the equitable income distribution more evident than ever. Stiglitz argues that 'those at the top of the distribution consume a smaller percentage of their income than those at the bottom causing weak aggregate demand unless the government undertakes offsetting actions' (Stiglitz, 2014). Accordingly, as a response to the economic crisis caused by the pandemic outbreak governments often provide direct payments to citizens in need. Such is the case with the USA, Spain, France, Germany and Denmark, to name a few - although to varying degrees in respect to the amount of the handouts and the policy designs.

The idea behind giving cash to people is the central idea to what is called a "universal basic income". Universal basic income is an unconditional and non-withdrawable income paid to every individual no matter how rich or poor that person is for the purpose of improving income inequality, neutralizing the negative effects of potential rising unemployment, providing safety nets to citizens, stimulating entrepreneurship, eradicating poverty, increasing economic growth through household consumption, etc. There have been calls during the coronavirus crisis for both an emergency basic income (an immediate basic income to protect individuals' incomes), for a recovery basic income (a basic income to be implemented with a view to preventing a recession once the virus outbreak begins to subside), and also for a permanent citizen's basic income schemes (Torry, 2020). The 2019 World Development Report focusing on the changing nature of work is suggesting that the social protection should be strengthened by expanding overall coverage that prioritizes the neediest people in society. A universal basic income is one of the possibilities to achieve this, but it is untested and fiscally prohibitive for emerging economies (World Bank, 2019).

Negative income tax as a policy is a lot less expensive compared to the universal basic income policy and more targeted at citizens in need. It does not provide cash to all citizens regardless of their income, but only to those who have incomes below the poverty threshold and just enough to reach the poverty threshold. Although the negative income tax as a policy is similar to the social protection policy it differs from it due to several crucial characteristics. Firstly, it is administered by the tax authorities instead of a range of social protection institutions lowering administration costs and increasing efficiency. Secondly, it does not impose any requirements on the citizens/receivers other than income related criteria - for example it is not obligatory to seek employment like it is the case with the guaranteed minimum income policy in Macedonia or use social services provided by government and vouchers for predetermined goods and services. Thirdly, it reaches a wider range of population making it more effective than conventional social protection policies while also reducing stigma among receivers.

The literature on negative income tax is extremely limited. To the author's best knowledge at the point of writing this paper it is practically non-existent for Macedonia and the wider geographic 
region of the Balkans. It should be noted that negative income tax has never been implemented by any country.

The theoretical background for this policy is pioneered by one of the most influential economists of the twentieth century and a Nobel Prize laureate Milton Friedman. Although famous for his work related to technical questions in economic theory, Friedman has also produced some of the most influential philosophical work on the role of government in a free society. His work is usually labeled as part of the neo-liberal political and economic thought and as such it is often reflected in the agendas of conservative political parties (Reitan, 2003). Friedman made a significant contribution to philosophical debates on freedom, and the link between political and economic freedom. According to Friedman, economic freedom as non-interference best promotes equality, opportunity, non-domination, democratic liberty, effective freedom (Preiss, 2015). In the terms of negative income tax this would mean that it is better for government to give cash handouts directly to citizens in need and leave the spending to their personal preferences than to predetermine what they need through complicated and expensive government programs.

Friedman originally proposed the negative income tax in his 1962 book Capitalism and Freedom, in a brief chapter on the welfare system (Moffitt, 2003). Theoretically, he proposed giving people a percentage of the difference between their income and the poverty threshold. For an example, if the poverty threshold is set at $\$ 40,000$, and the negative income tax percentage was 50 percent, someone who made $\$ 20,000$ would receive $\$ 10,000$ from the government. If they made $\$ 35,000$, they would receive $\$ 2,500$ from the government, meaning that people who work will always make more money than those who don't, which would ideally incentivize people to work (Linke, 2018).

The five advantages of negative income tax according to Friedman are: 1) it provides support to the poor solely on the basis of their income, and not on the basis of some other personal characteristic (age, sex, profession); 2) it provides cash which is the best form of support from the point of view of the recipient; 3 ) it provides a substitute to the multiple programs set up to affect income distribution; 4) it costs less than the existing system by saving administrative costs and by concentrating benefits more easily on the poor; 5) negative income tax does not distort market prices that minimum wages, tariffs, and farm supports do, which are often also argued on the basis of distributional considerations.

It should be noted that the negative income tax policy as proposed in this paper is supplemental to existing social policy programs and does not represent their substitute like it is proposed by Friedman. In addition, the calculation of the negative income tax amount as proposed in this paper is different from Friedman's. Aiming to provide all citizens living in poverty with the poverty threshold income, it is calculated as the difference between the poverty threshold income and the income that the poorest earn or receive in social transfers or pensions. For instance, if the poverty threshold is set at 97,000 MKD for a single person household, someone whose income is 72,000 MKD will receive an additional 25,000 MKD from the government, thus having a negative income tax rate of $25.77 \%$. Someone whose income is 48,000 MKD will receive an additional 49,000 MKD from the government, thus having a negative income tax rate of 50.51\%, etc. The calculation of the negative income tax as such is unique to this paper and to the author's best knowledge it has never been proposed in the existing literature so far. The issue of avoiding the problem of disincentivizing employment is not specifically addressed in this paper, having in mind that the disposable income of the individuals under this program would not go higher than 
approximately 8,000 MKD per month (monthly poverty threshold) - an amount that is almost half the minimum wage in Macedonia.

As per the World Bank data, the economic inequality in Macedonia measured by the Gini coefficient has declined in the period 2010 to 2018 by 9 percentage points. Despite this decline in the Gini coefficient, approximately 450,000 people in Macedonia still live in poverty (State Statistical Office, 2018). Having in mind that the income inequality decline could be a result of both raising income at the bottom or decreasing income at the top, the underlying causes should be further investigated. Analyzing the average annual income per household of the bottom $20 \%$ of the income distribution as a percent of the total average annual income per household it is noticeable that their income has increased for only 2.19 percentage points compared to Y2010 (Velkovska, 2020). In the same time, there is a decrease in the average annual household income of the top $20 \%$ of the income distribution by 7.38 percentage points indicating that this change reflects directly in the decrease of the Gini coefficient (Velkovska, 2020). From 2010 to 2018, the average net salary in Macedonia has increased for $20.18 \%$, the average retirement pension has increased for $35.31 \%$, the statutory minimum wage has increased for $51.11 \%$ compared to 2012 and the average social transfers have increased by 49,59\%. In the same time, the unemployment rate has decreased by 10.7 percentage points. However, in the same time, as stated above - the income of the bottom $20 \%$ of the income distribution has stagnated. These data make it evident that the social protection system and the economic system in general leave the poor on the margins of society.

In the next two sections, this analysis will try to provide an estimation of the costs of implementing negative income tax rate based on official, publicly available data. The cost of negative income tax could be calculated by determining the difference between the total income the poor population needs to reach poverty threshold and what this population already earns or receives as social transfers or pensions. The calculation should be simple and straightforward.

However, calculating the benefits of such policy for the overall economy is a complex task. The net costs or net benefits of such policy could not be determined without calculating the effects that negative income tax could have on the economy. The hypothesis of this research (as presented in section 4 of this paper) is that the negative income tax policy could increase economic growth through increasing household consumption. Poor people spend the most (if not all) of their income on goods and services that are part of the basic needs basket. These are usually domestic products and services produced and supplied within the local economy. Household spending is the essential driving force of economic growth - it represents more than half of GDP in most developed economies (Chai, 2018). This phenomenon is even more evident in small emerging markets who often find the consumer spending to be one of the engines of the economy. A study using yearly data series during 2004-2017 for eight CEE countries concluded that the economic growth in the CEE area is mainly based on the private consumption in the short run (Radulescu et al., 2019). Therefore, section four of this paper is an attempt to determine the relationship of household consumption and economic growth in Macedonia in order to better understand the potential benefits from a negative income tax policy.

\section{HOW MUCH WOULD NEGATIVE INCOME TAX COST?}

Social transfers historically make up for the largest percent of government expenditure in Macedonia and other social democracies. According to the 2020 State Budget in Macedonia, the planned social protection expenditure amounts up to $31 \%$ of all budget expenditure (State Budget RNM, 2020). Total planned social transfers are 116 billion MKD which is around 52\% 
of total planned budget revenues for year 2020. On the other hand, the poverty rate in Macedonia is as high as $22 \%$, counting a population of 455,100 people whose income is below the poverty threshold.

The State Statistical Office, based on the Survey on Income and Living Conditions, which is carried out in accordance with European Union recommendations, calculated Laeken poverty indicators for 2018 (State Statistical Office announcement, 2019). According to this database, the poverty threshold for single person household is 97,000 MKD (yearly income), meaning that the monthly poverty threshold for a single person household is approximately $8,000 \mathrm{MKD}{ }^{1}$

Table 1: Laeken indicators for 2018 used in calculations of the cost of the NIT

\begin{tabular}{|l|c|l|c|}
\hline Population Y2018 & $2,082,958$ & Poverty rate & $22 \%$ \\
\hline $\begin{array}{l}\text { Poverty threshold for } \\
\text { single person household } \\
\text { (MKD) }\end{array}$ & 97,000 & $\begin{array}{l}\text { Poverty threshold for } \\
\text { four person household } \\
\text { (MKD) }\end{array}$ & 203,700 \\
\hline $\begin{array}{l}\text { No. of people living in } \\
\text { poverty (total) }\end{array}$ & 455,100 & $\begin{array}{l}\text { No. of people living in } \\
\text { poverty (per centile) }\end{array}$ & 20,686 \\
\hline $\begin{array}{l}\text { No. of single person } \\
\text { households (total) }\end{array}$ & 113,775 & $\begin{array}{l}\text { No. of single person } \\
\text { households (per centile) }\end{array}$ & 5,172 \\
\hline $\begin{array}{l}\text { No. of four person } \\
\text { households (total) }\end{array}$ & 85,331 & $\begin{array}{l}\text { No. of four person } \\
\text { households (per centile) }\end{array}$ & 3,879 \\
\hline $\begin{array}{l}\text { Amount of minimum } \\
\text { income needed per centile } \\
\text { (MKD) }\end{array}$ & $1,291,734,119$ & $\begin{array}{l}\text { Amount of monthly } \\
\text { income needed per single } \\
\text { household (MKD) }\end{array}$ & 8,083 \\
\hline
\end{tabular}

(Source: Author's calculations using data from the Ministry of Finance and the State Statistical office available at the following links: http://www.stat.gov.mk/PrikaziSoopstenie.aspx?rbrtxt=115 and https://www.finance.gov.mk/mk/node/6608 )

The poverty threshold for four person households (two adults and two children less than 14 years old) amounts up to a yearly income of $203,700 \mathrm{MKD}$. In absence of precise data, for the purpose of this calculation, it is presumed that $25 \%$ of the people living with incomes below the poverty threshold are single person households and the other 75\% are four person households. Under this assumption, the total number of single person households is 113,775 - given that the total number of poor people is 445,100 . Accordingly, the number of four person households would be 85,331 - it is $75 \%$ of the number of people living in poverty divided by four.

Since the poverty rate is $22 \%$ of total population, for the purpose of this calculation, the focus is on the bottom 22 centiles of the income distribution. Following the above mentioned assumptions and in absence of data for the number of single person households and four person households per centile - it is necessary to make an additional assumption that all centiles that are subject to our analysis have the equal amount of single person households and four person households. That amounts for up to 5,172 single person households per centile and up to 3,879 four person households per centile.

\footnotetext{
${ }^{1}$ Although it is debatable whether this is the appropriate income level for defining the poverty threshold, this dilemma is not the subject of this paper. The official, publicly available and uniform data are being used in order to achieve consistency in the calculations.
} 
Having these assumptions in mind and knowing the poverty threshold yearly income for both single person households and four person households as determined by the State Statistical Office the calculation should be straightforward. This calculation is presented in the Table 2 below. The $22 \%$ of the population living in poverty or a total of 455,100 people are divided in the five centile groups as presented in the first column in Table 2. As explained in the previous section of this analysis - the NIT cost would be equal to the difference in the minimum poverty threshold yearly income needed for the $22 \%$ of the poorest of the total population and the income that the poorest $22 \%$ of the population currently earn or receive in social transfers or pensions.

In 2017, the Ministry of Finance has released data on income distribution per centiles for three years (Y2014, Y2015 and Y2016). Based on those data and the amount of income distributed in each centile, for the purpose of this calculation, the five centile groups have $90 \%, 45 \%, 10 \%, 5 \%$ and $1 \%$ of yearly income that is below the poverty threshold. In other words, the first five centiles of the income distribution have only $10 \%$ of the yearly income needed to reach the poverty threshold. The second five centiles of the income distribution have as much as $45 \%$ of the poverty threshold yearly income etc., while the population of the last two centiles have income that almost reaches the poverty threshold yearly income.

Table 2: Calculation of costs for the NIT

\begin{tabular}{|c|c|c|c|c|c|}
\hline $\begin{array}{c}\text { Centile } \\
\text { groups }\end{array}$ & $\begin{array}{c}\text { No. of } \\
\text { people in } \\
\text { poverty }\end{array}$ & $\begin{array}{c}\text { Percentage of } \\
\text { income below the } \\
\text { poverty threshold } \\
\text { income }\end{array}$ & $\begin{array}{c}\text { Total net } \\
\text { income of the } \\
\text { centile group } \\
\text { (MKD) }\end{array}$ & $\begin{array}{c}\text { Amount of } \\
\text { minimum } \\
\text { income needed } \\
\text { per centile } \\
\text { group (MKD) }\end{array}$ & $\begin{array}{c}\text { Difference } \\
\text { (MKD) }\end{array}$ \\
\hline $1-5$ & 103,432 & $90 \%$ & $645,867,060$ & $6,458,670,597$ & $5,812,803,537$ \\
\hline $6-10$ & 103,432 & $45 \%$ & $3,552,268,828$ & $6,458,670,597$ & $2,906,401,768$ \\
\hline $11-15$ & 103,432 & $10 \%$ & $5,812,803,537$ & $6,458,670,597$ & $645,867,060$ \\
\hline $16-20$ & 103,432 & $5 \%$ & $6,135,737,067$ & $6,458,670,597$ & $322,933,530$ \\
\hline $21-22$ & 41,373 & $1 \%$ & $2,557,633,556$ & $2,583,468,239$ & $25,834,682$ \\
\hline Total & 455,100 & & $18,704,310,048$ & $28,418,150,625$ & $\mathbf{9 , 7 1 3 , 8 4 0 , 5 7 7}$ \\
\hline
\end{tabular}

(Source: Author's calculations using data from the Ministry of Finance and the State Statistical office available at the following links:

http://www.stat.gov.mk/PrikaziSoopstenie.aspx?rbrtxt=115 and

https://www.finance.gov.mk/mk/node/6608)

The amount of minimum income needed per centile group is calculated by multiplying the number of single person households and four person households and the respective poverty threshold income. According to these calculations, each centile from the bottom $22 \%$ of the income distributions needs approximately a yearly income of 1.3 billion MKD (Table 1). Based on the available data and the above-mentioned assumptions and calculating the NIT cost as the difference between the amounts needed for the 22 centiles to reach the poverty threshold and their current disposable income, it can be concluded that the NIT policy reform would mean additional 9.7 billion MKD budget expenses per year (Table 2), which is $4 \%$ of the planned state budget revenues for Y2020, 8\% of the planned social transfers for Y2020 and 29\% of the funds that the state has already made available for tackling the COVID 19 crisis so far. 


\section{EMPIRICAL ANALYSIS - HOUSEHOLD CONSUMPTION AND GDP}

The empirical analysis testing the hypothesis that household consumption is one of the most important factors for increasing economic growth in Macedonia is presented in this section of the analysis. Proving that this hypothesis can be accepted is crucial in understanding the true cost of the negative income tax as a social policy because this policy should not be perceived as simply an increase in government expenditure but also as an investment in the whole economy through helping those in need.

The quarterly time series used for the purpose of this analysis is available at the Ministry of Finance statistical database and covers the period from 2001 - 2019. In order to test this hypothesis we model the GDP growth rate as a simple linear regression in which the household consumption, government consumption, investments, imports and export are the explanatory variables. This is the common expenditure approach to calculating the GDP based on the different spending groups that participate in the economy. For this purpose the following equation should be estimated:

$$
G D P=\alpha+\beta_{1} \text { HCons }+\beta_{2} \text { GCons }+\beta_{3} \operatorname{Inv}+\beta_{4} \operatorname{Imp}+\beta_{5} \operatorname{Exp}+\varepsilon
$$

where $\boldsymbol{G D P}$ is the GDP growth, HCons is the growth rate of the household consumption i.e. expenditure incurred by the citizens and households, GCons is the growth rate of the government consumption, $\boldsymbol{I n v}$ is the growth rate of the companies' investments, Imp is the growth rate of imports and $\boldsymbol{E x p}$ is the growth rate of exports. The data are on quarterly basis and the number of observations is $\mathrm{N}=76$.

In order to test whether our variables are stationary we used the Augmented Dickey-Fuller unit root test (Table 3). According to the results of the tests, the null hypothesis stating that there is unit root present in the trends of the variables is rejected because the probability values of all variables are less than 0.05 . Thus, the alterative hypothesis stating that the variables are stationary cannot be rejected i.e. should be accepted.

Table 3: Augmented Dickey-Fuller unit root tests

\begin{tabular}{|c|c|c|c|c|c|c|}
\hline Variable & GDP & HCons & GCons & Inv & Imp & Exp \\
\hline t-statistic & -5.9238 & -5.2134 & -4.3858 & -8.3468 & -6.1330 & -5.0319 \\
\hline p-value & 0.0000 & 0.0000 & 0.0007 & 0.0000 & 0.0000 & 0.0001 \\
\hline
\end{tabular}

(Source: Author's calculations using Eviews8 econometric software)

Knowing that all the variables have consistent arithmetic mean and variance throughout the analyzed period, what is left in order to inspect whether all the assumptions for using the ordinary least squares method are fulfilled, is to perform a heteroscedasticity test and a serial correlation test. In order to test for any existence of seasonal heteroscedasticity (Trimbur, 2006) the Breusch-Pagan-Godfrey test can be used. The result of the heteroscedasticity test show a pvalue that is larger than 0.05 indicating that the null hypothesis cannot be rejected (Table 4). This means that the error variances are all equal thus suggesting that there is no heteroscedasticity in the sample.

In order to test for serial correlation the Breusch-Godfrey LM test could be used. The results of the serial correlation test show a probability value that is larger than 0.05 indicating that the null hypothesis cannot be rejected (Table 5). This means that each observation is independent of one another thus suggesting that there is no serial correlation in the sample. 
Table 4: Breusch-Pagan-Godfrey heteroscedasticity test

\begin{tabular}{|c|c|}
\hline F-statistic & 1.1538 \\
\hline Prob. F(5,70) & 0.3406 \\
\hline Prob. Chi-Square(5) & 0.3275 \\
\hline
\end{tabular}

(Source: Author's calculations using Eviews8 econometric software)

Table 5: Breusch-Pagan LM serial correlation tests

\begin{tabular}{|c|c|}
\hline F-statistic & 0.0660 \\
\hline Prob. F(2,68) & 0.9361 \\
\hline Prob. Chi-Square(2) & 0.9290 \\
\hline
\end{tabular}

(Source: Author's calculations using Eviews8 econometric software)

After testing the applicability of the assumptions of the ordinary least squares method one can proceed to estimate the regression equation. The estimated regression equation is presented below.

$$
\begin{aligned}
& G D P=0.4749 * \text { HCons }+0.1075 * \text { GCons }+0.1061 * \text { Inv }-0.2887 * \text { Imp }+ \\
& 0.2452 * \text { Exp }+0.3870
\end{aligned}
$$

The results of the regression (Table 6) suggest that the model is well suited to explain the changes in the GDP growth showing a sufficiently high coefficient of determination with the value of $67.50 \%$. This means that a high percentage of the changes in the GDP growth can be explained by the changes in the chosen explanatory variables.

Table 6: Regression results of the estimated equation

\begin{tabular}{|c|c|c|c|c|}
\hline Variable & Coefficient & Std. Error & t-Statistic & Prob. \\
\hline HCONS & 0.4749 & 0.0662 & 7.1695 & 0.0000 \\
\hline GCONS & 0.1075 & 0.0333 & 3.2291 & 0.0019 \\
\hline INV & 0.1061 & 0.0110 & 9.5751 & 0.0000 \\
\hline IMP & -0.2887 & 0.0415 & -6.9481 & 0.0000 \\
\hline EXP01 & 0.2452 & 0.0340 & 7.2112 & 0.0000 \\
\hline C & 0.3870 & 0.4039 & 0.9582 & 0.3412 \\
\hline
\end{tabular}

(Source: Author's calculations using Eviews8 econometric software)

The slope coefficient of the variable HCons (household consumption) has a positive sign and it takes a value of 0.4749 with a probability value of 0.0000 meaning that this result is statistically significant with a probability of $100 \%$. This means that for the given sample when the household consumption growth rate rises for 1 unit, the GDP growth rate also rises for 0.4749 units (in this case percentage points). The slope coefficient for the variable GCons (government consumption) has a positive sign and takes a value of 0.1075 with a probability value of 0.0019 meaning that this result is statistically significant with a $99 \%$ probability. This means that for the given sample when the government consumption growth rate increases for 1 percentage point, the GDP growth rate will increase for 0.1075 percentage points. The slope coefficient for the variable Inv (companies' investments) has a positive sign and takes a value of 0.1061 with a probability value of 0.0000 meaning that this result is statistically significant with a $100 \%$ probability. This means 
that for the given sample when the companies' investments growth rate increases for 1 percentage point, the GDP growth rate also increases for 0.1061 percentage points. The slope coefficient for the variable $\operatorname{Imp}$ (import) has a negative sign and takes a value of 0.2887 with a probability value of 0.0000 meaning that this result is statistically significant with a $100 \%$ probability. This means that for the given sample when the imports growth rate increases for 1 percentage point, the GDP growth rate decreases for 0.2887 percentage points. The slope coefficient for the variable Exp (exports) has a positive sign and takes a value of 0.2452 with a probability value of 0.0000 meaning that this result is statistically significant with a $100 \%$ probability. This means that for the given sample when the exports growth rate increases for 1 percentage point, the GDP growth rate also increases for 0.2452 percentage points.

The results suggest that the change in the GDP growth rate is in highest correlation with the growth rate in household consumption out of all explanatory variables, thus confirming the research hypothesis of this analysis. Second to the household consumption in terms of high correlation with the dependent variable is the exports growth rate. The variables related to companies' investments and the government consumption show a somewhat smaller but also positive slope coefficient and the only variable with negative slope coefficient to GDP growth is the imports growth rate.

According to the above, the results from the empirical analysis for the given sample and chosen variables for the time period from 2001 to 2019 for the Macedonian economy are in line with what the consulted literature suggests - the household consumption is one of the most important engines of economic growth.

\section{CONCLUSION}

Poverty, income inequality and high unemployment are one of the most persistent concerns in the Macedonian society. Almost half a million people live below the poverty threshold in Macedonia and this number is expected to rise as the COVID-19 pandemic crisis develops. The economic decline is expected to endure even in the aftermath of the pandemic crisis, thus exacerbating these issues even further. Governments all around the world are finding new innovative ways to tackle this unprecedented situation in the economy. Although to a varying degrees in respect to the granted amount and diverse policy designs, many countries have implemented policies that envisage direct payments to citizens similar to the concept of universal basic income. However, this policy can be an expensive option for small economies with limited fiscal space. Another policy option that could target citizens in need in an effective way is implementing a negative income tax. This policy option is rarely discussed in academic circles and policy debates and could easily be labeled as progressive and unconventional. Although these challenging times call for innovative ideas, it cannot be denied that any policy reforms are as good as they are financially feasible. Due to this fact, this paper had aimed to explain what negative income tax is and provide an estimation of the potential costs arising from it.

The negative income tax rate was first proposed by Milton Friedman, a Nobel Prize winner and one of the most influential economists in the $20^{\text {th }}$ century who is often associated with the neoliberal economic thought. His idea of a negative income tax would be a cash-based substitute to the existing social welfare protection programs aiming at decreasing administration costs, increasing policy effectiveness while improving individual freedom of the citizens living in poverty. It should be noted that the negative income tax as proposed in this paper would not be supplemental to the existing social protection system in Macedonia, but would represent an additional and complementary policy in order to make the existing social welfare more effective 
and inclusive. Unfortunately, in the last decade in Macedonia, despite the fact that the average net salary has increased for $20.18 \%$, the average retirement pension has increased for $35.31 \%$, the statutory minimum wage has increased for $51.11 \%$ and the average social transfers have increased by $49.59 \%$, the income of the bottom $20 \%$ of the population has stagnated, indicating that these changes do not reach the poorest in the country. These developments are indicating that there is a need to reinvent the current social protection paradigm and find innovative ways to build a more resilient system.

The poverty rate for Y2018 in Macedonia is $22 \%$ meaning that $22 \%$ of the population live with incomes less that the poverty threshold income. Calculated as the difference between the amounts needed for the 22 centiles to reach the poverty threshold and their current disposable income, it can be concluded that the NIT policy reform would mean additional 11 billion MKD state budget expenses per year, which is $4 \%$ of the planned state budget revenues for Y2020, 8\% of the planned social transfers for Y2020 and 29\% of the funds that the state has already made available for tackling the COVID 19 crisis so far.

Since estimating the cost of the negative income tax policy would not be complete without calculating the positive effect it could have on the overall economy, this paper tested the hypothesis that the negative income tax policy could increase economic growth through increasing household consumption. In an attempt to determine the relationship of household consumption and economic growth in Macedonia, the results of this paper suggest that the change in the GDP growth rate is in highest correlation with the growth rate in household consumption out of all explanatory variables (government consumption, investments, export and import). For the given sample, the results indicate that when the household consumption growth rate rises for 1 percentage point, the GDP growth rate also rises for 0.4749 percentage points. Due to the fact that poor people use all of their income on domestic consumption rather than saving, it could be expected that the policy of negative income tax would be beneficial for the economic growth in Macedonia while also improving the lives of those who live in poverty.

\section{REFERENCES:}

Chai, A. (2018), "Household consumption patterns and the sectoral composition of growing economies: A review of the interlinkages", available at:

https://www.unido.org/api/opentext/documents/download/10166980/unido-file-10166980

(accessed 15 June 2020)

Eurostat (2018), "Glossary - at risk of poverty rate", available at:

https://ec.europa.eu/eurostat/statistics-explained/index.php/Glossary:At-risk-of-poverty rate

(accessed 15 June 2020)

International Labour Organization (2020), "ILO Monitor 2nd edition: COVID-19 and the world of work, Updated estimates and analysis", available at:

https://www.ilo.org/wcmsp5/groups/public/---dgreports/---

dcomm/documents/briefingnote/wcms 740877.pdf (accessed 15 June 2020).

Linke, R. (2018), "Negative Income Tax, explained”, available at: https://mitsloan.mit.edu/ideasmade-to-matter/negative-income-tax-explained (accessed 15 June 2020)

Ministry of Finance of North Macedonia (2020), "State Budget of Republic of North

Macedonia", available at: https://finance.gov.mk/mk/node/4105 (accessed 15 June 2020) 
Moffit, A. R. (2003), "The Negative Income Tax and the Evolution of U.S. Welfare Policy", available at: https:/www.degruyter.com/view/journals/bis/10/2/article-p169.xml?tab body=pdf74962 (accessed 15 June 2020).

Preiss, J. (2015), "Milton Friedman on Freedom and the Negative Income Tax", available at: https://www.degruyter.com/view/journals/bis/10/2/article-p169.xml?tab body=pdf-74962 (accessed 15 June 2020)

Radulesku, M., Serbanesku, L. and Sinisi, I. C. (2019), "Consumption vs. investments for stimulating economic growth and employment in the CEE countries", available at:

https://www.tandfonline.com/doi/pdf/10.1080/1331677X.2019.1642789?needAccess=true (accessed 15 June 2020)

Reitan, E. A. (2003), The Thatcher revolution: Margaret Thatcher, John Major, Tony Blair, and the transformation of Modern Britain, 1979-2001, Oxford: Rowman \& Littlefield.

State Statistical Office (2018), "News Release - Laeken poverty indicators in 2018", available at: http://www.stat.gov.mk/pdf/2019/4.1.19.116 mk.pdf (accessed 15 June 2020)

Stiglitz, E. J. (2014), "Reforming taxation to promote growth and equity", available at:

https://www8.gsb.columbia.edu/faculty/jstiglitz/sites/jstiglitz/files/Reforming\%20Taxation\%20R oosevelt\%20Paper.pdf (accessed 01 April 2020).

Torry, M. (2020), "Evaluation of a Recovery Basic Income, and of a sustainable revenue neutral Citizen's Basic Income, with an appendix relating to different Universal Credit roll-out scenarios", available at: https://www.euromod.ac.uk/publications/evaluation-recovery-basicincome-and-sustainable-revenue-neutral-citizen $\% \mathrm{E} 2 \% 80 \% 99 \mathrm{~s}$-basic-income (accessed 15 June 2020)

Trimbur, M. T. (2006), "Seasonal heteroscedasticity in time series data: modeling, estimation and testing" available at: https://ec.europa.eu/eurostat/documents/4578629/4579718/TRIMBURFINAL.pdf (accessed 15 June 2020)

Velkovska, I. (2020), "Economic inequality in Macedonia and the effects of different types of personal income on the total income in the first quantile of the income distribution", working paper, Faculty of Economics Skopje, University St. Cyril and Methodius, 14 March

World Bank (2019), "World development report 2019 - The changing nature of work", available at: https://www.worldbank.org/en/publication/wdr2019 (accessed 15 June 2020) 